DigitALCOMMONS @WAYNESTATE -

\section{Michigan Journal of Counseling: Research, Theory and Practice}

Volume 36 | Issue 1

Article 1

3-1-2009

\title{
From the Editorial Desk
}

Arnold Coven

Wayne State University

Follow this and additional works at: https://digitalcommons.wayne.edu/mijoc

\section{Recommended Citation}

Coven, A. (2009). From the Editorial Desk, Michigan Journal of Counseling, 36(1), i. doi:10.22237/mijoc/1235865600

This From the Editor is brought to you for free and open access by the Open Access Journals at DigitalCommons@WayneState. It has been accepted for inclusion in Michigan Journal of Counseling: Research, Theory and Practice by an authorized editor of DigitalCommons@WayneState. 


\section{From the Editorial Desk}

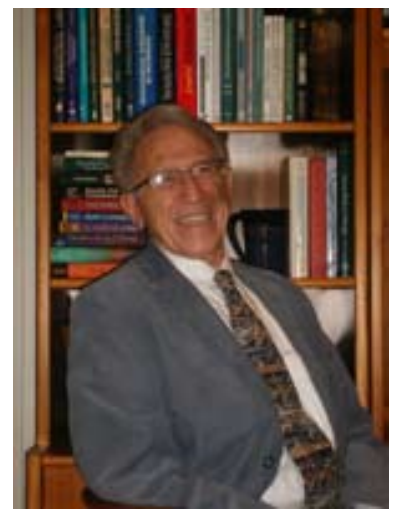

Arnold Coven, Ed.D.

Editor

Dr. Coven is an Associate

Professor of Counselor

Education at Wayne

State University
This year has been a struggle for the Michigan Counseling Association. The budget deficit and remaining contractual obligations have threatened our very existence. It has been gratifying to see how the leadership has worked together to meet these challenges. I have also been impressed by leaders in our divisions who have worked with their membership to come up with ways to help the association financially. With all the difficulties, the leaders and members continue to demonstrate a professional attitude and commitment to our counseling profession. The editors of our newsletter have continued to update the members on counseling issues and events. The editorial board members of our Journal have worked diligently to publish this spring- summer issue. The Michigan Association for Specialists in Group Work conducted a workshop on counseling problem children in groups. This division was recognized by the national ASGW with an award banner as the outstanding group work division in the country. Thus, despite our challenges, MCA leadership and membership continue to fulfill our mission of increasing our knowledge and skills to further our professional identity.

The first article, by professors Hawley and Calley, address the effort of professional counselors to attain broader recognition. They propose a fivestep action plan that represents a multipronged strategy to promote the counseling profession as a distinct field in mental health treatment. The unique values of multiculturism, advocacy, humanistic philosophy, and importance of conducting research highlights this comprehensive conceptualization presentation.

In the second article, the authors address how self-identity is influenced by ethnicity and acculturation. Research findings are presented that support acculturation and ethnic identity as two distinct elements that differentiate ethnic groups. A measure of ethnic identity is presented in an effort to recognize the relationships with several demographic variables. The research findings support a significant relationship between total ethnic identity of students of English as second language and identity achievement. Using the research results, the authors point out how understanding of ethnic identity affects counselors' and educators' interactions with students, which can lead to more positive relationships.

Authors of the third article recommend a triage system used by hospitals and mental health centers to screen school students to determine their mental health needs. An assessment tool to systematically screen large groups of students is presented and described in detail. In implementing this 'easy to use' procedure, school counselors are helped to know their students and can demonstrate their commitment to address every child's social and emotional needs. 